\title{
A study on clinico-epidemiological profile of typhoid fever in a rural based medical college \& hospital; West Bengal; India
}

\author{
Bandyopadhyay S. ${ }^{1}$, Pal A. C. ${ }^{2}$, Dey S. ${ }^{3}$, Samanta S. ${ }^{4}$, Chakraborti S. ${ }^{5}$, Mandal R. ${ }^{6}$ \\ ${ }^{1}$ Dr. Sudipta Bandyopadhyay, Post Graduate Trainee, ${ }^{2}$ Dr. Abhay Charan Pal, Associate Professor, ${ }^{3}$ Dr. Subhendu \\ Dey, Assistant Professor; ${ }^{4}$ Dr. Subhendu Samanta, Post Graduate Trainee; ${ }^{5}$ Dr. Snehansu Chakraborti, Professor \\ and HOD, above all authors affiliated with Department of Pediatric Medicine, B.S Medical College, Bankura, \\ West Bengal, India, ${ }^{6}$ Dr Ramkrishna Mandal, Professor, Department of Surgery, B.S Medical College, Bankura, \\ West Bengal, India.
}

Corresponding Author: Dr. Abhay Charan Pal, Associate Professor, Department of Pediatric Medicine, B.S Medical College, Bankura, West Bengal, India, E-mail: abhaypal80@gmail.com

\begin{abstract}
Introduction: Typhoid fever is estimated to have caused 26.9 million cases and 5.74 lakhs deaths worldwide in 2010. It remains a major public health problem in India and other part of developing world. Background: Nonprovision of safe drinking water and sanitation measures, non-implementation of adequate vaccination strategies and emergence of multidrug resistant salmonella strains is responsible for why typhoid fever is till now remaining an important health problem in some parts of world and the disease is even becoming more complex. Objective: This study was conducted in a tertiary care centre to find out the clinico-epidemiological profile of patients admitted with typhoid fever. Design: Cross sectional observational study. Subjects: 460 Widal positive typhoid fever pediatric cases admitted from $1^{\text {st }}$ June 2016 to $30^{\text {th }}$ November 2016. Methods: Both clinical and laboratory data of all the patients were retrieved, compiled and analyzed. Results: Out of 460 patients $238(51.74 \%)$ were males and 222 (48.26\%) were females. Fever (100\%), vomiting (49.13\%), diarrhea (30.21\%), cough (30.0\%) and hepatomegaly (73.26\%) were commonly observed.Response to injection Ceftriaxone was excellent.355(77.17\%) patients responded to Ceftriaxone alone and 99 (21.52\%) patients needed addition of oral Azithromycin.Average hospital stays in our study ranged from 3-9 days. Conclusion: In the present series typhoid fever accounted for $10.94 \%$ of pediatric admissions. Though mortality has significantly reduced typhoid fever continues to be an important cause of hospitalization in pediatric population.High incidence among lower age group indicates high endemicity and emphasizes the need of widespread use of vaccination.
\end{abstract}

Keywords: Cross-sectional, Observational study; India; Rural based Medical College Hospital; Typhoid fever.

\section{Introduction}

Typhoid fever is a systemic infection caused by Salmonella enterica serovar Typhi (S Typhi)[1]. S typhi, a highly adapted human-specific pathogen that evolved around 5000 years ago, has remarkable mechanisms for persistence in its host $[1,2,3]$.

Though provision of clean water and good sewage system has led to great decline in the incidence of typhoid fever in Europe and the USA since the early $20^{\text {th }}$ century; the disease has remained a serious public health problem in developing countries $[4,5]$.

Manuscript received: $6^{\text {th }}$ December 2017

Reviewed: $16^{\text {th }}$ December 2017

Author Corrected: $24^{\text {th }}$ December 2017

Accepted for Publication: $30^{\text {th }}$ December 2017
Advent of Chloramphenicol treatment has changed typhoid fever from a serious, often fatal disease to a readily manageable infection $[5,6]$. Even after the development of Chloramphenicol resistant strains in 1972, the isolates were still sensitive to Cotrimoxazole, Ampicillin and Amoxycillin[1]. Out breaks of typhoid caused by strains resistant to Chloramphenicol, Co-trimoxazole, Ampicillin and Amoxycillin were reported in late 1980s and 1990s [6].

Currently Fluoroquinolones and third generation cephalosporins are the drugs of choice in typhoid fever but decreased susceptibility to these 
antimicrobials has been reported [7,10]. Possible emergence of an untreatable strain may be prevented by prudent use of existing drugs and resisting the temptation to use yet more antimicrobials[1].

Typhoid fever imposes a serious global burden amounting to 26.9 million cases (symptomatic infection with Salmonella typhi) of typhoid fever reported in 2010 and apparently 5.74 lakh deaths worldwide [11]. Inspite of provision of safe water and sanitation, better treatment and vaccination, burden of the disease in certain areas of the Globe is however remaining quite high and moreover the disease is becoming more complex in certain areas of World like some parts of African Subcontinent $[1,12]$.

There has been intense study regarding the genomics of $\mathrm{S}$. typhi and the genetic mechanism behind its unique human-adaptiveness. There has been exciting new genetic technological innovation to demonstrate that the same genes in S. typhi and S.typhimurium may have different regulatory pathways and different function [12]. This under standing may help for developing newer target for vaccine development and new antibacterial drug for S.typhi in endemic areas.

The different genes responsible for development of drug resistance in S.typhi are haplotype 58(H58), a group of plasmids, incH11, gyrA and gyrB genes etc accounting for resistance against Fluoroquinolones and other agents[1,13,14].

Two types of vaccine are in current use namely purified Vi polysaccharide vaccine and a new conjugate vaccine (less widely available). Though programmatic use of vaccine in high-risk population has been advocated by WHO, only a few countries have taken such actions; namely Pondichery(India) in 2004 after Tsunami, Fiji in 2010 after cyclone Tomas and Sri Lanka in 2009 after the civil war and some other countries like Pakistan, Nepal and china[12,15,16]. Clinical presentation of typhoid fever is highly variable ranging from only fever with little other morbidity to marked toxemia and multisystem involvement.

Complications include gastrointestinal bleeding (10$20 \%)$; intestinal perforation (1-3\%); neuropsychiatric symptoms like coma vigil (around 2\%) and severe complications like DIC and death [1].

\section{Original Research Article}

With modern treatment; if initiated early, the average case fatality ratio for typhoid fever is less than $1 \%$; however mortality as high as $30-50 \%$ has been reported from Papua New Guinea and Indonesia for severe typhoid fever[17,18].

Treatment may range from oral medications like Fluoroquinolones (Ofloxacin, Ciprofolxacin); combination of Ciprofloxacin and Amoxycillin; combination of Ciprofloxacin and Gentamycin; oral Cefixime and Azithromycin (Quinolone-resistant cases) and injectable Ceftriaxone or Cefotaxime for severe typhoid fever $[19,20]$.

An increase in incidence of typhoid fever has been reported from countries like India, Pakistan and Indonesia; younger populations are more likely to be involved in areas with high incidence rates $(>100 / 100000$ population/year)[1,21].

Considering the global disease burden, rapidly evolving multidrug resistant typhoid strains, changing clinical profile and variable case fatality rate this observational study was conducted in a tertiary care Medical College Hospital. The intention of this study was to find out the disease burden, clinical profile and efficacy of the commonly used treatment regimens in admitted typhoid patients. The study results may help to contemplate treatment and prevention strategies like implementation of effective vaccination programs as advocated by the WHO apart from elevation of water supply and sanitation measures.

\section{Materials and Methods}

Study Design: Cross-sectional observational study

Place: The Department of Pediatrics; BS Medical College; Bankura; West Bengal; India.

Duration: Study period extended from $1^{\text {st }}$ June2016 to $30^{\text {th }}$ November 2016.

Sample size: 460 cases of Widal positive typhoid fever cases admitted in the Pediatric ward BS Medical College Hospital.

Studypopulation: Patients fulfilling the inclusion criteria and none satisfying the exclusion criteria.

\section{Inclusioncriteria}

1. Fever (temp $>37.5^{\circ} \mathrm{c}$ ) for at least 5 days and serum Widal test positive (O titre $>1: 160$ or $\mathrm{H}$ titre $>1: 160)[22.23]$. 
The above case definition is very close to the WHO case definition[24].

2. Parents of patients who gave informed and written consent.

\section{Exclusioncriteria}

1. Patients having fever less than 5 days.

2. Patients with Widal test negative

3. All the fever patients having serum Widaltitre less than 1:160 for $\mathrm{O}$ and/or $\mathrm{H}$ antigen

4.All the patients who left the study or took discharge against medical advice or not willing to give consent.

Methods: Detailed clinical examination of all the patients were carried out and laboratory work up was done. Complete blood count and Widal test was performed in all children and Chest $X$ ray, USGabdomen, CT or MRI brain, CSF examination and other investigations were done as and when necessary.

All the cases were treated with injectable Ceftriaxone and Oral Azithromycin was added if the patients remained febrile after 5 days of injectable Ceftriaxone. Patients were closely monitored for

\section{Original Research Article}

development of any complications and were treated accordingly.

As most patients came after 1 week of fever and because of technical constraints culture could not be done.

Rather we performed tube agglutination test (Widal) against $\mathrm{O}$ and $\mathrm{H}$ antigens for the diagnosis of typhoid fever considering sufficient sensitivity and specificity and cost-effectiveness.

Widal test is easier to perform and also less time consuming. Blood culture, though is taken as gold standard lacks sensitivity and our institute does not have good set up for the same [25].

Statistical Methods: Data analysis was done using SPSS20 software. Standard statistical tests were applied. Rate and proportions were calculated with $95 \%$ confidence intervals and level of significance was set up at $\mathrm{P}<.05$.

Permission from IEC/IRB: Necessary permission for conducting the study and to publish the results observed were obtained from the Institutional Ethics Committee/ Institutional Review Board of this College.

\section{Results}

Table-1: Shows the age and sex distribution of typhoid fever.

\begin{tabular}{|c|c|c|c|}
\hline Age(years) & Total patients(n=460) & Male (n=238(51.74\%)) & Female (n=222(48.26\%)) \\
\hline$<1$ & $10(2.17 \%)$ & $6(2.52 \%)$ & $4(1.8 \%)$ \\
\hline $1-<2$ & $58(12.61 \%)$ & $30(12.6 \%)$ & $28(12.61 \%)$ \\
\hline $2-<5$ & $150(32.61 \%)$ & $76(31.93 \%)$ & $74(33.34 \%)$ \\
\hline $5-<10$ & $162(35.22 \%)$ & $85(35.72 \%)$ & $77(34.68 \%)$ \\
\hline$\geq 10$ & $80(17.39 \%)$ & $41(17.23 \%)$ & $39(17.57 \%)$ \\
\hline
\end{tabular}

Out of total 460 patients, 238 were males and 222 females giving a male: female ratio of 1.07 .

Age wise incidence shows highest incidence in 5-<10years age group (162 patients, 35.21\%) and lowest incidence in $<1$ year age group (10 patients, $2.17 \%$ ).

Remarkable finding was rising incidence in $<2$ year age group (14.77\%) which indicates changing trend of the disease.

Age- wise distribution of signs-symptoms shows that fever was present in all $460(100 \%)$ patients. Almost all infants (<1year) presented with diarrhea, hepatomegaly and vomiting.

Hepatomegaly was observed with remarkably high frequency in all age groups. 
Table-2: Demonstrate age-related clinical features of typhoid fever.

\begin{tabular}{|c|c|c|c|c|c|c|}
\hline $\begin{array}{c}\text { Age } \\
\text { (year) }\end{array}$ & $\begin{array}{c}\text { Fever } \\
(n=460)\end{array}$ & $\begin{array}{c}\text { Vomiting } \\
(n=226)\end{array}$ & $\begin{array}{c}\text { Diarrhea } \\
(n=139)\end{array}$ & $\begin{array}{c}\text { Coated tongue } \\
(n=76)\end{array}$ & $\begin{array}{c}\text { Hepatomegaly } \\
\quad(n=337)\end{array}$ & $\begin{array}{l}\text { Splenomegaly } \\
(n=190)\end{array}$ \\
\hline$<1(\mathrm{n}=10)$ & $10(100 \%)$ & $7(70 \%)$ & $10(100 \%)$ & $1(10 \%)$ & $10(100 \%)$ & $7(70 \%)$ \\
\hline $\begin{array}{c}1-<2 \\
(n=58)\end{array}$ & $\begin{array}{c}58 \\
(100 \%)\end{array}$ & $\begin{array}{c}30 \\
(51.72 \%)\end{array}$ & $\begin{array}{c}22 \\
(37.93 \%)\end{array}$ & $5(8.62 \%)$ & $42(72.41 \%)$ & $7(12.06 \%)$ \\
\hline $\begin{array}{c}2-<5 \\
(n=150)\end{array}$ & $\begin{array}{c}150 \\
(100 \%)\end{array}$ & $\begin{array}{c}56 \\
(37.34 \%)\end{array}$ & $\begin{array}{c}44 \\
(29.34 \%)\end{array}$ & $18(12 \%)$ & $118(78.67 \%)$ & $60(40 \%)$ \\
\hline $\begin{array}{c}5-<10 \\
(n=162)\end{array}$ & $\begin{array}{c}162 \\
(100 \%)\end{array}$ & $\begin{array}{c}92 \\
(56.79 \%)\end{array}$ & $\begin{array}{c}42 \\
(25.92 \%)\end{array}$ & $36(22.23 \%)$ & $108(66.67 \%)$ & $62(38.27 \%)$ \\
\hline $\begin{array}{c}\geq 10 \\
(n=80)\end{array}$ & $\begin{array}{c}80 \\
(100 \%)\end{array}$ & $\begin{array}{c}41 \\
(51.25 \%)\end{array}$ & $\begin{array}{c}21 \\
(26.25 \%)\end{array}$ & $16(20 \%)$ & $59(73.75 \%)$ & $54(67.5 \%)$ \\
\hline
\end{tabular}

Table-3: Illustrates overall distribution of clinical features of typhoid fever taking into account all age groups.

\begin{tabular}{|c|c|c|}
\hline Clinical features & No of Patients $(\mathbf{n}=\mathbf{4 6 0})$ & \% \\
\hline Fever & 460 & 400 \\
\hline Vomiting & 226 & 30.21 \\
\hline Diarrhea & 139 & 66.52 \\
\hline Anorexia & 306 & 69.13 \\
\hline Malaise, bodyache, headache & 318 & 30.0 \\
\hline Cough & 138 & 3.91 \\
\hline Altered sensorium & 18 & 3.48 \\
\hline Convulsion & 16 & 1.08 \\
\hline Intestinal perforation & 5 & 1.30 \\
\hline Intestinal hemorrhage & 6 & 73.26 \\
\hline Hepatomegaly & 337 & 41.30 \\
\hline Splenomegaly & 190 & 20.43 \\
\hline
\end{tabular}

Apart from fever which was present in all cases; hepatomegaly $(73.26 \%)$, malaise, bodyacheand headache $(69.13 \%)$, anorexia $(66.52 \%)$, splenomegaly $(41.30 \%)$, vomiting $(49.13 \%)$ and diarrhea $(30.21 \%)$ were the main presenting features.

Table-4: Elaborates hematologicalprofile observed in typhoid fever cases.

\begin{tabular}{|c|c|c|c|c|c|c|c|}
\hline \multirow{2}{*}{$\begin{array}{c}\text { Age } \\
\text { (years) } \\
n=460\end{array}$} & \multicolumn{3}{|c|}{$\begin{array}{c}\text { Hemoglobin level (Anemia } \mathrm{n}= \\
106(23.04)(\mathrm{gm} / \mathrm{dl})\end{array}$} & \multirow{2}{*}{$\begin{array}{c}\text { Leucocytosis } \\
\left(>10000 / \mathrm{mm}^{3}\right) \\
n=81(17.6 \%)\end{array}$} & \multirow{2}{*}{$\begin{array}{l}\text { Leucopenia } \\
\left(<4000 / \mathrm{mm}^{3}\right) \\
\mathrm{n}=184(40 \%)\end{array}$} & \multirow{2}{*}{$\begin{array}{c}\text { Eosinopenia } \\
\text { (no eosiniphil } \\
\text { in PBS) } \\
\mathrm{n}=66 \\
(14.34 \%)\end{array}$} & \multirow{2}{*}{$\begin{array}{l}\text { Thrombo } \\
\text { cytopenia } \\
(<1.5 \mathrm{lak} / \\
\left.\mathrm{mm}^{3}\right) \mathrm{n}=50 \\
(10.87 \%)\end{array}$} \\
\hline & $\begin{array}{l}< \\
7\end{array}$ & $\begin{array}{c}7-\leq 11 \\
n=106 \\
(23.04 \%)\end{array}$ & $>11$ & & & & \\
\hline$<1(\mathrm{n}=10)$ & 0 & 0 & $10(100 \%)$ & $6(60 \%)$ & 0 & 0 & 0 \\
\hline $\begin{array}{c}1-<2 \\
(\mathrm{n}=58)\end{array}$ & 0 & $14(24.13 \%)$ & $\begin{array}{c}44 \\
(75.87) \\
\end{array}$ & $19(32.75 \%)$ & $21(36.2 \%)$ & $5(8.62 \%)$ & 0 \\
\hline $\begin{array}{c}2-<5 \\
(n=150)\end{array}$ & 0 & $37(24.67 \%)$ & $\begin{array}{c}113 \\
(75.33 \%)\end{array}$ & $23(15.34 \%)$ & $52(34.67 \%)$ & $28(18.67 \%)$ & $\begin{array}{c}14(9.34 \% \\
)\end{array}$ \\
\hline $\begin{array}{c}5-<10 \\
(n=162)\end{array}$ & 0 & $37(22.84 \%)$ & $\begin{array}{c}125 \\
(77.16 \%) \\
\end{array}$ & $23(14.2 \%)$ & $70(43.2 \%)$ & $23(14.2 \%)$ & $\begin{array}{c}24(14.81 \\
\%)\end{array}$ \\
\hline $\begin{array}{c}\geq 10 \\
(\mathrm{n}=80)\end{array}$ & 0 & $18(22.5 \%)$ & $\begin{array}{c}62 \\
(77.5 \%)\end{array}$ & $10(12.5 \%)$ & $41(51.25 \%)$ & $10(12.5 \%)$ & $12(15 \%)$ \\
\hline
\end{tabular}


Anemia was observed in $23.04 \%$ of cases while $17.6 \%$ of cases had leucocytosis. $40 \%$ of typhoid fever cases showed leucopenia and eosinopenia was seen in $14.34 \%$ of cases. Thrombo cytopenia was noted in $10.87 \%$ of cases. Remarkably leucocytosis was found in younger populations; $60 \%$ in less than 1-year age group and $32.75 \%$ in $1-<2$ year age group.

Table-5: Elaborates the antibiotics used in our study and the response obtained.

\begin{tabular}{|c|c|c|}
\hline Antibiotics & No of patients (n=460) & \% \\
\hline Inj Ceftriaxone alone & 355 & 77.17 \\
\hline Inj Ceftriaxone+ Oral Azithromycin & 99 & 21.52 \\
\hline Other drugs & 6 & 1.31 \\
\hline
\end{tabular}

All patients (460) were started treatment with inj. Ceftriaxone after inclusion in the study. Out of them $355(77.17 \%)$ responded. In $99(21.52 \%)$ patients oral Azithromycin had to be added on $5^{\text {th }}$ or $6^{\text {th }}$ day of Ceftriaxone therapy. Inj. Cefoperazone and inj. Amoxyclav were needed in 6 patients (3 each).

Table-6: Shows the duration of hospitalization in the study population with typhoid fever.

\begin{tabular}{|c|c|c|}
\hline $\begin{array}{c}\text { Duration of Hospitalization } \\
\text { (days) }\end{array}$ & $\begin{array}{c}\text { No of Patients } \\
\text { (n=460) }\end{array}$ & \% \\
\hline$<3$ & 70 & 15.21 \\
\hline $3-6$ & 106 & 23.04 \\
\hline $6-9$ & 239 & 51.95 \\
\hline$>9$ & 45 & 9.80 \\
\hline
\end{tabular}

$51.95 \%$ of patients required hospital stay of 6to 9 days; while $9.8 \%$ patients had to be kept in Hospital for more than 9 days. Those patients requiring longer hospital stay, had complications like intestinal perforation, hemorrhage, convulsion and altered sensorium. Only 15.21\% patients could be discharged within 3 days.

\section{Discussion}

Typhoid fever continues to be a significant cause of morbidity in children in developing countries. In the present series typhoid fever accounted for $10.94 \%$ of pediatric admissions (460 out of 4200). The majority of cases were seen between 5-10 years of age similar to earlier observation[26]. Highest clustering of cases was observed in the months of August to October. This findingalso corroborated with earlier finding by other researchers [27].

There is an increasing trend of incidence of typhoid fever in children younger than two years. In our series $14.77 \%$ cases occurred below 2 years, among them $2.17 \%$ (out of 460 ) cases occurred below 1 year $(p<.05)$. Similar findings were noted by other observers also who found high incidence of typhoid fever below 2 years of age [28,29]. In our series high incidence of typhoid fever was noted in children below 5 years $(47.37 \%)$, which is also due to the fact that our institute is located in a highly typhoid endemic area. This finding is consistent with observations of earlier researchers which showed high incidence of typhoid fever in younger children in highly endemic areas [30]. The high disease burden in preschool children in our study emphasizes the need of vaccination program and improvement in potable water supply and sanitation [31]. In our series $51.74 \%$ of cases were male and $48.26 \%$ children were females making male: female ratio 1.07 , like earlier observation $[21,32]$.

In this study common presenting complaints were fever (100\%); hepatomegaly $\quad(73.26 \%)$; splenomegaly (41.30\%); anorexia (66.52\%); malaise, bodyache and headache (69.13\%); vomiting (49.13\%) and diarrhea (30.21\%).

Rare but important complications in our series were altered sensorium and 'coma vigil' i.e. muttering delirium (3.91\%); convulsion (3.48\%); intestinal perforation (1.08\%) and intestinal hemorrhage $(1.30 \%)$. Similar observations were also made by earlier workers in this field though rates of complications were somewhat lower in our series 
$[32,33]$. The zero mortality in our study was mostly due to less complications and early intervention whenever complications were detected and a quite good PICU set-up. Only one child out of 5 cases of intestinal perforation required surgical intervention.

The mortality profile $(0 \%)$ in our series is consistent with observation by other workers [32,33].

Hematological profile in our study revealed anemia in $23.04 \%$ of cases; leucocytosis and leucopenia in $17.6 \%$ and $40 \%$ cases respectively; eosinopenia in $14.34 \%$ children and thrombocytopenia in $10.87 \%$ of cases. These hematological alterations were consistent with findings by earlier researchers excepting incidence of leucopenia [33].

Leucopenia was observed in $40 \%$ of cases with highest incidence $(51.25 \%)$ in children in the age group above 10 years $(\mathrm{p}<.05)$.

Logistic regression analysis comparing patients with and without complications revealed that presence of prolonged fever( $>1$ week), eosinopenia, elevation of AST, splenomegaly and lack of typhoid vaccination were associated with high risk of complications; similar to observations by other researchers $[32,33]$.

In our series $77.17 \%$ patients became afebrile within 6-7 days of IV Ceftriaxone therapy. In only $21.52 \%$ of cases Azithromycin had to be added to Ceftriaxone. Treatment with other drugs namely inj. Cefoperazone and inj. Amoxyclav was required in $1.13 \%$ of cases. Similar trends were observed in other series also $[32,33]$.

Only $28 \%$ of patients in our series received $\mathrm{Vi}$ capsular polysaccharide vaccine and vaccine efficacy in our series was only $42 \%$ (calculated by the formula: (incidence among unimmunizedincidence among immunized)/ incidence among unimmunized).

The mean duration of hospital stay in our series was 6.7 days which is in conformity with observations by other researchers [33]. In our study Widal test was used as the diagnostic test for typhoid fever because of its cost-effectiveness, availability and rapid performance. Blood culture though considered the gold- standard is not feasible in all settings, lacks specificity and may be false-negative in cases with prior antibiotic treatment [34,35].

\section{Conclusions}

Typhoid fever continues to be a major public health problem in children worldwide. In our series typhoid fever hadaccounted for $10.94 \%$ of all pediatric admissions. Global emergence of multidrug resistant strains with reduced susceptibility to Fluoroquinolones is of great concern. Control of typhoid fever relies on clinical information, diagnosis and on understanding of epidemiology of the disease. Different Salmonella sppserovars causing enteric fever have very different ancestries and vaccines are not cross-protective. Public health interventions to minimize human carrier contact, improved personal hygienic measures, incorporation of typhoid vaccination in immunization schedule and inhibition to use of antibiotics in an irrational manner will definitely go a long way to reduce the disease burden both on a short-term and a long-term basis.

Our study shows the pattern of typhoid fever in this part of the country and changing trend affecting younger population; emphasizing the need for implementation of typhoid vaccination (including newly innovated conjugate typhoid vaccine) in a wider scale in highly endemic areas.

Larger studies in this field specially in regions with high incidence of typhoid fever is needed for better understanding of the epidemiology of the disease and hence better disease- control.

\section{Author's Contributions}

- Dr Bandyopadhyay performed the entire work. He collected datas from all the cases and compiled them. He performed the statistical analysis.

- Dr Pal conceived the idea and contemplated the study plan. He actually drafted the final manuscript and revised the same by adding many intellectual contents.

- Dr Deyprovided all sorts of technical guidance and assistance for the work.

- Dr Samanta assisted Dr Bandyopadhyay in the study at all points and maintained all coordination with the departments ofPathology, Radiology, Biochemistry and Microbiology as and whenever needed.

- Dr Chakraborti gave necessary guidance during the study. He also added some intellectual contents. 
- Dr Mandal provided technical assistance in the study and managed the surgical emergencies in the present series. He also contributed some intellectual contents.

Funding: Nil, Conflict of interest: None initiated, Perission from IRB: Yes

\section{References}

1. Bhan MK, Bahl R, Bhatnagar S. Typhoid and paratyphoid fever.Lancet. 2005 Aug 27-Sep 2;366 (9487): 749-62.

2. Kidgell C, Reichard U, Wain J, Linz B, Torpdahl M, Dougan G, Achtman M. Salmonella typhi, the causative agent of typhoid fever, is approximately 50,000 years old.Infect Genet Evol. 2002 Oct;2(1): $39-45$.

3. Osler W. The principles and practice of medicine: designed for the use of practitioners and students of medicine. 8th edn. New York: D Appleton, 1912: $1-46$.

4. Crump JA, Luby SP, Mintz ED. The global burden of typhoid fever. Bull World Health Organ. 2004 May;82(5):346-53.

5. Woodward TE, Smadel JE, Ley HL Jr, Green R, Mankikar DS. Preliminary report on the beneficial effect of chloromycetin in the treatment of typhoid fever. 1948. Wilderness Environ Med. 2004 Fall;15 (3): $218-20$.

6. Mirza SH, Beeching NJ, Hart CA. Multi-drug resistant typhoid: a global problem.J Med Microbiol. 1996 May;44(5):317-9.

7. Rowe B, Ward LR, Threlfall EJ. Multidrugresistant Salmonella typhi: a worldwide epidemic. Clin Infect Dis. 1997 Jan; 24 Suppl 1: S106-9.

8. Mehta G, Randhawa VS, Mohapatra NP. Intermediate susceptibility to ciprofloxacin in Salmonella typhi strains in India. Eur J Clin Microbiol Infect Dis. 2001 Oct;20(10):760-1.

9. Harish BN, Madhulika U, Parija SC. Isolated high-level ciprofloxacin resistance in Salmonella enterica subsp. enterica serotype Paratyphi A. J Med Microbiol 2004; 53: 819.

\section{Original Research Article}

10. Saha SK, Talukder SY, Islam M, Saha S. A highly ceftriaxone-resistant Salmonella typhi in Bangladesh. Pediatr Infect Dis J. 1999 Apr;18 (4): 387.

11. Buckle GC, Walker CL, Black RE. Typhoid fever and paratyphoid fever: systematic review to estimate global morbidity and mortality for 2010 . J Glob Health 2012; 2: 10401

12. Wain J, Hendriksen RS, Mikoleit ML, Keddy KH, Ochiai RL. Typhoid fever. Lancet. 2015 Mar 21; 385 (9973):1136-45. doi: 10.1016/S0140-6736 (13)62708-7. Epub 2014 Oct 21.

13. Mirza S, Kariuki S, Mamun KZ, Beeching NJ, Hart CA. Analysis of plasmid and chromosomal DNA of multidrug-resistant Salmonella enterica serovar Typhi from Asia. J ClinMicrobiol 2000; 38 : 1449-52.

14. Holt KE, Phan MD, Baker S, et al. Emergence of a globally dominant IncHI1 plasmid type associated with multiple drug resistant typhoid. PLOS Neg1 Trop Dis 2011; 5: e1245.

15. Typhoid vaccines: WHO position paper.Wkly Epidemiol Rec. 2008 Feb 8;83(6):49-59.

16. DeRoeck D, Ochiai RL, Yang J, Anh DD, Alag V, Clemens JD. Typhoid vaccination: the Asian experience. Expert Rev Vaccines 2008; 7: 547-60.

17. Punjabi NH, Hoffman SL, Edman DC, Sukri N, Laughlin LW, Pulungsih SP, Rivai AR, Sututo, Moechtar A, Woodward TE. Treatment of severe typhoid fever in children with high dose dexamethasone. Pediatr Infect Dis J. 1988 Aug;7 (8): 598-600.

18. Rogerson SJ, Spooner VJ, Smith TA, Richens J. Hydrocortisone in chloramphenicol-treated severe typhoid fever in Papua New Guinea.Trans R Soc Trop Med Hyg. 1991 Jan-Feb; 85(1): 113-6.

19. Mandal S, Mandal MD, Pal NK. Combination effect of ciprofloxacin and gentamicin against clinical isolates of Salmonella enterica serovar typhi with reduced susceptibility to ciprofloxacin.Jpn J Infect Dis. 2003 Aug; 56(4):156-7. 
20. Dutta P, Mitra U, Dutta S, De A, Chatterjee MK, Bhattacharya SK. Ceftriaxone therapy in ciprofloxacin treatment failure typhoid fever in children. Indian J Med Res. 2001 Jun;113:210-3.

21. Ganesh R, Janakiraman L, Vasanthi T, Sathiyasekeran M. Profile of typhoid fever in children from a tertiary care hospital in Chennai-South India. Indian J Pediatr. 2010 Oct; 77(10):1089-92. doi:10.1007/s12098-010-0196-9. Epub 2010 Sep 30.

22. Desai P, Vijapura A.Y. Profile of typhoid fever in admitted pediatric patients from tertiary care hospital. Pediatr Rev: Int J Pediatr Res 2015; 2(4):75-79.doi:10.17511/ijpr.2015.4.009.

23. Kundu R, Ganguly N, Ghosh TK, Yewale VN, Shah RC, Shah NK; IAPTask Force.IAP Task Force Report: diagnosis of enteric fever in children.Indian Pediatr. 2006 Oct;43(10):875-83.

24.Background Document: The diagnosis, treatment and prevention of typhoid fever. WHO /V\&B/03.07 (case definitions taken directly from this document without alterations).

25. Wain J, Hosoglu S. The laboratory diagnosis of enteric fever.J Infect Dev Ctries. 2008 Dec 1;2(6): 421-5.

26. Walia M, Gaind R, Paul P, Mehta R, Aggarwal P, Kalaivani M. Walia M, Gaind R, Paul P, Mehta R, Aggarwal P, Kalaivani M. Trans R Soc Trop Med Hyg. 2006 Oct;100(10):942-8.

27. Siddiqui FJ, Rabbani F, Hasan R, Nizami SQ, Bhutta ZA. Typhoid fever in children: some epidemiological considerations from Karachi, Pakistan. Int J Infect Dis. 2006 May;10(3):215-22. Epub 2006 Jan 23.

28. Verma M, Chhatwal J, Saini V, Singh T. Enteric fever below 2 years of age. Indian Pediatr. 1996 Mar;33(3):229-30.
Original Research Article

29. Saha SK, Baqui AH, Hanif M, Darmstadt GL, Ruhulamin M, Nagatake T, Santosham M, Black RE. Typhoid fever in Bangladesh: implications for vaccination policy.Pediatr Infect Dis J. 2001 May;20 (5): 521-4.

30. Sinha A, Sazawal S, Kumar R, Sood S, Reddaiah VP, Singh B, Rao M, Naficy A, Clemens JD, Bhan MK. Typhoid fever in children aged less than 5 years. Lancet. 1999 Aug 28;354(9180):734-7.

31. Ochiai RL, Acosta CJ, Danovaro-Holliday MC, Baiqing D, Bhattacharya SK, Agtini MD, Bhutta ZA, Canh DG, Ali M, Shin S, Wain J, Page AL, Albert MJ, Farrar J, Abu-Elyazeed R, Pang T, Galindo CM, von Seidlein L, Clemens JD; Domi Typhoid Study Group. A study of typhoid fever in five Asian countries: disease burden and implications for controls.Bull World Health Organ. 2008 Apr;86(4):260-8.

32. Kundu R, Ganguly N, Ghosh TK, Yewale VN, Shah RC, Shah NK; IAP Task Force. IAP Task Force Report: management of enteric fever in children. Indian Pediatr. 2006 Oct;43(10):884-7.

33. Ganesh R, Janakiraman L, Vasanthi T, Sathiyasekeran M. Profile of typhoid fever in children from a tertiary care hospital in Chennai-South India. Indian J Pediatr. 2010 Oct;77(10):1089-92.doi: 10.1007/s12098-010-0196-9. Epub 2010 Sep 30.

34. Lavanya V, Shivakumar S Solabannavar,Suresh B Sonth. Comparison of Results Obtained by Semiquantitative Slide Agglutination and Tube Widal Tests in the Diagnosis of Suspected Typhoid Fever Cases. International Journal of Biological \& Medical Research. 2013; 4(1): 3001-3003.

35. Rasaily R, Dutta P, Saha MR, Mitra U, Bhattacharya SK, Manna B, Mukherjee A, Chakravorty S Pal SC.Value of a single Widal test in the diagnosis of typhoid fever.Indian $\mathrm{J}$ Med Res.1993May;97:104-7.

\section{How to cite this article?}

Bandyopadhyay S, Pal A. C, Dey S, Samanta S, Chakraborti S, Mandal R. A study on clinico-epidemiological profile of typhoid fever in a rural based medical college \& hospital; West Bengal; India. Int J Pediatr Res. 2017;4(12):713-720. doi:10.17511/ijpr.2017.i12.03. 